\title{
Histological and Histochemical Methods for Staining of Insulin: A Comparative Analysis
}

\author{
Meyramov GG*, Meyramova-Abdraimova AG, Shaybek AS and Karaganda KZ \\ Diabetes Research Group, Karaganda State University, Kazakhstan
}

Received: 眥 January 01, 2019; Published: 眥 January 22, 2019

*Corresponding author: Gabit G Meyramov, Diabetes Research Group, Karaganda, Kazakhstan

\section{Short Communication}

Various histochemical and histological methods are used for analysis of the state of histostructure and of insulin content in pancreatic B-cells. Aim of work: a comparative analysis of the results of using of 3 staining technologies refined and detailed by us: Aldehyde fucshine, AF, fluorescent diethylpseudoisocyanine method, PS and Dimethylnaphtylmetan, V4 (Victoria 4R, color index 42563). Intensity of fluorescence of A-chair of insulin (PS) measured using of histofluorimetric complex [1]. Calculation of parameter FL= IF1/IF2 where IF2-intensity of fluorescence of intact B-cells (as 1.00) and IF1-B-cells in diabetes. Density of color (AF and V4), parameter DC= DC1/DC2 where DC2-density of color of intact B-cells (as 1.00) and DC1-B-cells in diabetes.

\section{Results}

\section{Aldehyde-Fucshine Method}

Violet granules in cytoplasm of B-cells correspond to deposited form of insulin [2,3]. Intensity of color of cytoplasm of B-cells directly correspond to insulin content in cytoplasm]. Staining procedures modified by us.

a. Deparaffinization of sections in xylol in 3 portions of xylol;
b. Alcohol $100^{\circ}-5 \mathrm{~min}$,
c. Alcohol $100^{\circ}-5 \mathrm{~min}$,
d. Alcohol $80^{\circ}-5 \mathrm{~min}$,
e. Water- $5 \mathrm{~min}$,
f. Oxidation $0,5-2 \mathrm{~min}$ oxidation solution: $5 \mathrm{ml}$ of $5 \%$ $\mathrm{H}_{2} \mathrm{SO}_{4}+5 \mathrm{ml} \mathrm{2,5 \%}$ solution of $\mathrm{KMnO}_{4}+30 \mathrm{ml}$ bidistilled water at $+28^{0}$ Celsius -2 min,

g. $2 \%$ solution of oxalic acid-rinse until discoloration,

h. Distil. water-5 min,

i. Aldehyde fucshine ("MERCK"; "SERVA")-5-7 min, j. Dcidified alcohol $70^{\circ}$ №1 - differentiate,

k. Acidified alcohol $70^{\circ}$ №2 - differentiate,

l. Halmy's solution-1 min,

m. Distil. water-5 min,

n. Distil. water №2-5 min,

o. Alcohol $100^{0}-5 \mathrm{~min}$,

p. Alcohol $100^{\circ}$ №2-5 $\min$,

q. Xylol- $5 \mathrm{~min}$,

r. Xylol №2 - 5 min,

s. Balm,

\section{Result:}

Violet color of insulin in B-cells (Figure 1.1) (intact animals; 1.4 in animals with diabetes).

\section{Diethylpseudoisocyanine Fluorescent Method}

Schiebler T. and Schiessler S. showed that A chair of oxidized insulin reacted with Diethylpseudoisocyanine chloride with formation of red fluorescent complex which fluoresces in UV light 360-370 $\mathrm{nm}$. We have used modernized method [4,5]. Staining procedures. Preparing of staining solution: $0,4 \%$ water solution of Diethylpseudoisocyanine (SERVA, Germany). Staining procedures:
a. Deparaffinization of sections in xylol;
b. Alcohol $90^{\circ}, 80^{\circ}, 70^{\circ} 1 \mathrm{~min}$ in each;
c. Washing in cold water;

d. Oxidation 0,5-2 min; Oxidation solution: $5 \mathrm{ml}$ of $5 \%$

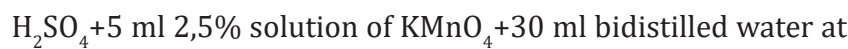
$+28^{0}$ Celsius;

e. Washing in cold water; 
f. $\quad 5 \%$ solution of oxalic acid $-5 \mathrm{sec}$;

g. Washing in 2 portions of cold water;

h. $0,4 \%$ cold solution of Diethylpseudoisocyanine - 20 min in refrigerator at $+4^{\circ}$ Celsius; i. Washing in cold water $5 \mathrm{~min}$;

j. Store in refrigerator 1,5-3h. Result Intensive red fluorescence of insulin in B-cells (Figure 1.2) intact animals; 1.5 in animals with diabetes) (Table 1).

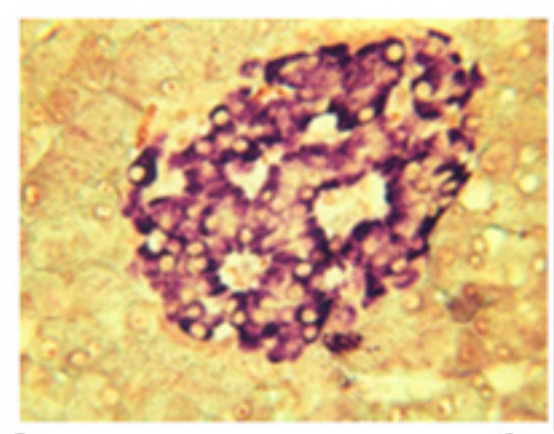

2

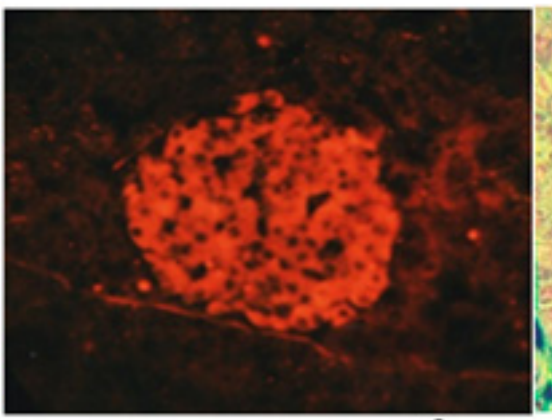

3
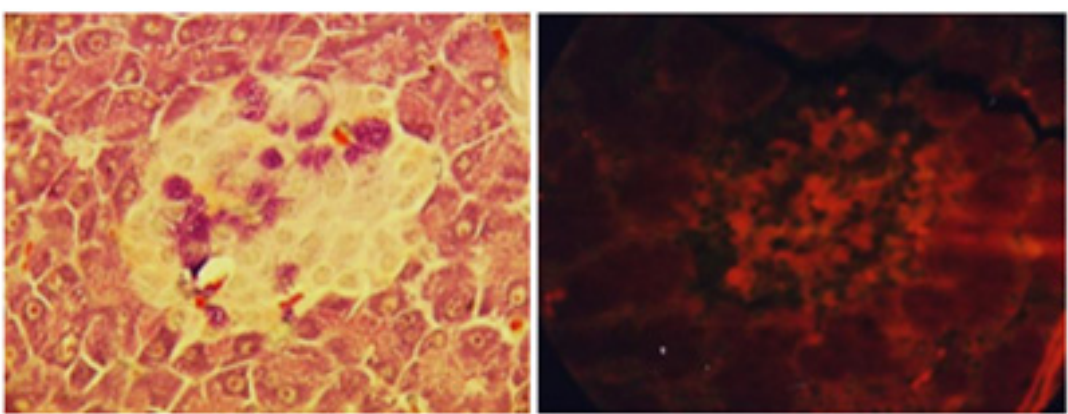

4

5

6
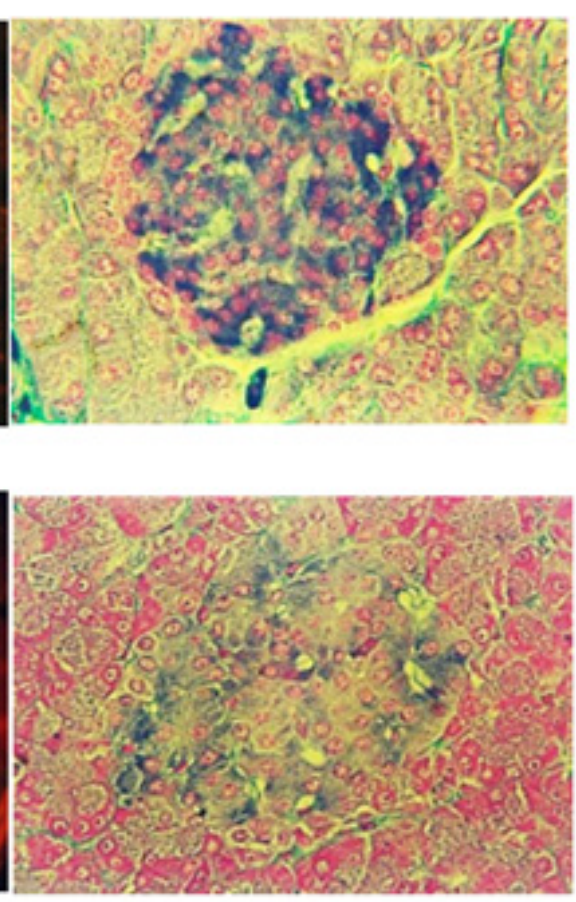

Figure 1: 1-3 - intact animals; 4-6 - animals with diabetes.

Table 1: Result Intensive red fluorescence of insulin in B-cells (Figure 1.2) intact animals; 1.5 in animals with diabetes).

\begin{tabular}{|c|c|c|c|c|c|}
\hline № & Staining Technology & Intact & Diabetes & Positive Properties of Method & Negative Properties of Method \\
\hline 1 & Aldehyde-fucshin & $\begin{array}{c}1.00 \pm 0.08 \\
n=18\end{array}$ & $\begin{array}{c}0.22 \pm 0.05 \\
n=23\end{array}$ & $\begin{array}{l}\text { a good opportunity for inves-tigation of } \\
\text { histotopography of in-sulin in B-cells and of } \\
\text { state of histostructure; precise method for } \\
\text { investigate of insulin content }\end{array}$ & \\
\hline 2 & Diethylpseudoisocyanine & $\begin{array}{c}1.00 \pm 0.03 \\
n=20\end{array}$ & $\begin{array}{c}0.12 \pm 0.02 \\
\mathrm{n}=25\end{array}$ & $\begin{array}{l}\text { minimal fluctuations of indicators of insulin } \\
\text { content; high sensitivity and specifity for } \\
\text { insulin; precise method for investigate of } \\
\text { insulin content }\end{array}$ & $\begin{array}{l}\text { only fresh staining secti- ons of } \\
\text { tissue can be used. }\end{array}$ \\
\hline 3 & Dimethylnaphtylmetan & $\begin{array}{c}1.00 \pm 0.10 \\
\mathrm{n}=24\end{array}$ & $\begin{array}{c}0.29 \pm 0.06 \\
\mathrm{n}=19\end{array}$ & $\begin{array}{l}\text { high specifity for insulin; prefe-rable for } \\
\text { investigation of histostru-cture of islets }\end{array}$ & $\begin{array}{l}\text { marked fluctuations indi-cators of } \\
\text { insulin conent }\end{array}$ \\
\hline
\end{tabular}

\section{Victoria Blue 4R Method Staining of Insulin (V4R)}

Diphenylnaphthylmetane, colour index 42563; MERCK, Germany; FERAK,Germany). It was showed (8) that V4R aqueous solution interacted with oxidized A-chair of insulin that is accompanied by painting of cytoplasm of B-cells in a blue color proportionally to the amount of insulin [6,7]. Staining procedures:

a. Deparaffinization of sections,

b. Washing in cold water a few min,

c. Oxidation 3-5 min(oxidation solution: $0,3 \% \mathrm{KMnO}_{4} 50$ $\mathrm{ml}+0,3 \% \mathrm{H}_{2} \mathrm{SO}_{4} 50 \mathrm{ml}$; wash sections, d. Place sections in 2-5\% water solution of sodium bisulphate - 1 min; wash sections,

e. $\quad 70^{\circ}$ alcohol- $1 \mathrm{~min}$,

f. Stain in staining solution $\left(96^{\circ}\right.$ alcohol $100 \mathrm{ml}+$ Victoria Blue 4R - 1g) 15 min - 2h; wash sections,

g. Stain on $0,5 \%$ water solution of Phloxine 30-120 sec.; wash sections;

h. $\quad 5 \%$ water solution of phosphor wolframic acid 1-2 min; wash section in water; 
i. Stain in 0,5\% water solution of Light Green 1-2 min;

j. Dehydratation in $96^{\circ}$ alcohol;

k. Balm. Result: blue color of insulin in B-cells; red color of A-cells (Figure 1) (intact animals; 1.6 in animals with diabetes).

\section{References}

1. Meyramov GG, Tusupbekova GT, Meyramova RG (1987) Histofluorimetric method measuring of insulin content in pancreatic B-cells. Problems of Endocrinology. Moskva 33(6): 49-51.

2. Kvistberg D, Lester G, Lasarov A (1966) Staining of insulin with aldehyde fucshin //J.Histochem. Cyto- chem 14: 609-611.

3. Ortman R, Forbes W (1966) Balasnalubramanian A., Concerning the staining properties of aldehyde basic fucshin. J Histochem 14: 104-111.

4. Coalson RE (1966) Pseudoisocyanine staining of insulin and specifity of empirical islet cell stain Stain Technol 41(12): 121-129.

\section{ISSN: 2574-1241}

DOI: $10.26717 / B J S T R .2019 .13 .002400$

Gabit G Meyramov. Biomed J Sci \& Tech Res

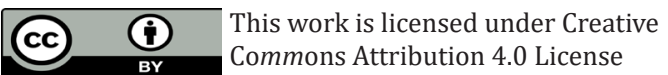

Submission Link: https://biomedres.us/submit-manuscript.php
5. Meyramov GG, Kikimbaeva AA, Meyramova AG (2005) The High specific fluorescent method for insulin revealing in B-cells of isolated pancreatic islets. Acta Diabetologica, the International diabetes journal.-SPRINGER 42(1): 66.

6. Kikui Y, Seguchi H, Mizoguti HA (1977) Differential staining method for A- and B-cells in the pancreatic islets of Langerhans. Acta Histochem. Cytochem 10(1): 10-13.

7. Meyramov GG, Meyramova AG, Kikimbaeva AA (2003) Victoria 4R Method Staining of Insulin in B-cells of Isolated Pancreatic Islets. ACTA DIABETOLOGICA, the International Diabetes Journal. SPRINGER 40(4): 208.

8. Wohlrab F, H Hahn von Dorsche, Krautschik I, Schmidt S (1985) On the specifity of insulin staining by Victoria Blue4R. Histochemical Journal 17(5): 515-518.

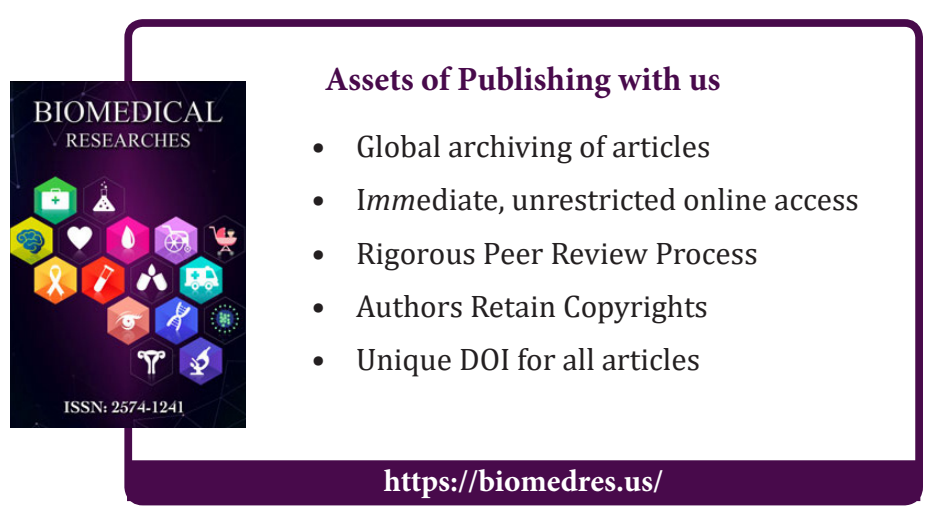

